\title{
ANALISIS PENERAPAN PEMBAYARAN ROYALTI HAK CIPTA LAGU PADA USAHA HIBURAN KARAOKE (Studi Kasus Orange Family Karaoke)
}

\author{
ANALYSIS OF THE IMPLEMENTATION OF THE ROYALTIES OF \\ SONG COPYRIGHT PAYMENTS ON ENTERTAINMENT OF KARAOKE \\ ENTERPRISES (Case Study of Orange Family Karaoke)
}

\author{
Suci Permata \\ Faculty of Law, University of Bandar Lampung \\ e-mail: Sucipermataa99@gmail.com \\ Tami Rusli \\ Faculty of Law, University of Bandar Lampung \\ e-mail: tami.rusli@ubl.ac.id \\ Melisa Safitri \\ Faculty of Law, University of Bandar Lampung \\ e-mail: melisa.safitri@ubl.ac.id
}

\begin{abstract}
Abstrak
Tempat karaoke banyak diminati dari berbagai kalangan. Semua tempat karaoke memiliki tujuan yang sama yaitu untuk memberikan hiburan bagi keluarga atau sejenak melepas penat dari rutinitas hari. Tempat karaoke selalu menyuguhkan lagu-lagu dengan berbagai pilihan dari semua kreasi penyanyi Indonesia. Namun tentunya lagu-lagu yang disuguhkan telah dilisensikan terlebih dahulu. Berkaitan dengan lisensi ini, pada dasarnya harus disepakati oleh kedua belah pihak tanpa paksaan. Perlindungan hak cipta, khususnya untuk musik atau kreasi lagu, merupakan masalah serius. Keadaan ini menunjukkan masih perlunya perlindungan hukum yang lebih ketat terkait perlindungan royalti atas suatu karya cipta lagu atau musik dan perlindungan hak-hak yang terkandung di dalamnya. Tujuan penelitian adalah mengetahui pelaksanaan pembayaran royalti hak cipta atas lagu antara pencipta dengan pelaku usaha hiburan karaoke dan faktor penghambat pembayaran royalti hak cipta atas lagu antara pencipta dan pelaku dalam hiburan karaoke di Karaoke keluarga Orange. Metode yang digunakan dalam penelitian adalah yuridis empiris. Data yang telah tersusun secara sistematis dianalisis secara kualitatif. Hasil penelitian menunjukkan bahwa pembagian hasil royalti dikelola oleh Lembaga Manajemen Kolektif (LMK). Lembaga tersebut diberi kuasa oleh pencipta untuk melaksanakan hak ekonomi pencipta. Penghambat pembayaran royalti karena masih kurangnya sosialisasi dan pemahaman dalam pembayaran royalti serta biaya pembayaran royalti yang terlalu mahal.
\end{abstract}

Kata Kunci: Royalti, Hak Cipta, Karaoke 


\section{Abstract}

Karaoke places are in great demand from various circles. All karaoke places have the same goal, which is to provide entertainment for the family or take a moment to unwind from the daily routine. Karaoke places always serve songs with various choices from all the creations of Indonesian singers. But of course the songs that are served have been licensed first. Regarding this license, basically it must be agreed by both parties without coercion. Copyright protection, especially for music or song creations, is a serious problem. This situation shows that there is still a need for stricter legal protection regarding the protection of royalties on a song or music copyrighted work and the protection of the rights contained therein. The purpose of the study was to determine the implementation of copyright royalty payments on songs between the creator and karaoke entertainment business actors and the inhibiting factors for the payment of copyright royalties on songs between the creator and performer in karaoke entertainment at Orange Family Karaoke. The method used in this research is empirical juridical. The data that has been systematically arranged were analyzed qualitatively. The results showed that the distribution of royalties is managed by the Collective Management Institute (LMK). The institution is authorized by the creator to exercise the economic rights of the creator. The barrier to royalty payments is due to the lack of socialization and understanding of royalty payments and the high cost of royalty payments.

Keywords: Royalty, Copyright, Karaoke

\section{A. Introduction}

The development of the karaoke business is also increasing, this is evidenced by the presence of a karaoke business from various classes, both ordinary to five-star class. Karaoke places are in great demand from various groups, ranging from children to the elderly. All karaoke places have the same purpose, namely to provide entertainment for the family or for a moment to release fatigue from the day's routine. It is not uncommon for this to be one of the family's choices for entertainment when gathering. Karaoke places always present songs with a variety of choices from all the creations of
Indonesian singers. But of course the songs that have been presented have been licensed beforehand.

In accordance with Article 1 point 1 of the Copyright Law itself is the exclusive right of a creator that arises automatically based on the declarative principle after a work is manifested in a tangible form without reducing restrictions in accordance with the provisions of laws and regulations In Article 4 of the Copyright Law, Copyright is an exclusive right consisting of moral rights and economic rights. However, it should be noted that exclusive rights are rights reserved only for the 
Creator, so that no other party can take advantage of these rights without the author's permission. Copyright holders who are not creators only have a part of the exclusive rights in the form of economic rights.

Meanwhile, it should be noted that what is meant by transferable or transferable is only economic rights, while moral rights remain attached to the Creator. Transfer of Copyright must be done clearly and in writing either with or without a notary deed. Regarding the transfer of moral rights, based on Article 5 paragraph (2) of the Copyright Law, moral rights cannot be transferred as long as the Author is still alive, but the exercise of these rights can be transferred by will or other reasons in accordance with the provisions of statutory regulations after the Creator dies .

Then in Article 1 number 20 of the Copyright Law concerning License Holders, the License Holder is a party who is granted a written permission granted by the Copyright Holder or Related Rights Owner to exercise economic rights over his work or Related Rights products with certain conditions. Related to Article 80 paragraph (2) of the Copyright Law This license is granted through a license agreement which is valid for a certain period of time and does not exceed the validity period of the Copyright and Related Rights. In Article 80 paragraph (3) of the Copyright Law, the Licensee will later provide Royalties to Copyright Holders or Related Rights owners for the duration of the License, unless agreed otherwise. Licensee can also be said to be a Copyright Holder but as a Copyright Holder for a certain time and for certain things as agreed in the license agreement. When the license agreement has expired, the party is no longer the Copyright Holder. $^{1}$

In connection with this license, it is necessary to pay attention to several important things that the license by its nature is an agreement which basically must be agreed upon by both parties without coercion.As an agreement, whether you are a user / user of a music copyright or a creator / rights holder Cipta (as a power of attorney), which is the parties to the agreement, basically can negotiate to reach an agreement in the agreement. In the negotiation, things can be discussed, which also concern your interests as the user, including the scope of use of the copyright work, whether to use it for your own interests or for commercial

${ }^{1}$ Alfons, M. (2018). Implementation of intellectual property rights in the perspective of a rule of law. Journal of Indonesian Legislation, 14 (3), 301-311. 
purposes. Where if a copyright work is used for its own interests there is no obligation to pay royalties.

Copyright protection, especially for music or song creations, is a serious problem. This situation shows that there is still a need for tighter legal protection related to the protection of royalties for a song or music copyright work and the protection of the rights contained therein. In connection with this, the authors make this study to examine the implementation of the rules of Law Number 28 of 2014 concerning copyright by examining the implementation of royalty payments and the obstacles encountered in implementing the law. Orange Family Karaoke is located at Jalan Kimaja Icon, Blok D number 68, Sepang Jaya, Labuham Ratu, Bandar Lampung. It is a family entertainment place specifically for a singing house which currently has 12 karaoke rooms.

\section{B. RESEARCH METHODS}

The approach used in this research is a normative juridical approach and an empirical juridical approach to obtain correct and objective research results. Then for the data analysis process, the data that has been arranged systematically are analyzed in a qualitative juridical manner, namely by providing an understanding of the data in accordance with the facts obtained in the field, so that it really is from the subject matter. on hand and arranged in sentence by sentence. which is scientific and systematic in the form of answers to problems based on research results.

\section{DISCUSSION}

1. The implementation of royalty payments for hipta rights over songs between the creators and the karaoke entertainment business actor. Case Study Orange family karaoke

Law Number 28 of 2014 provides comprehensive protection for creators, copyright holders and related rights owners. Law Number 28 of 2014 is an amendment to Law Number 19 of 2002. Amendments to this Law are intended to provide more protection to creators, copyright holders and related rights owners, that as is known in Law Number 28 of 2014 there were improvements and improvements and provided more protection for creators, copyright holders and related rights owners, especially in responding to current developments in information and technology, and this is as stated in several articles in the latest Copyright Law.

Legal protection for song or music works came later than legal protection for written works (literature). Likewise, the 
protection of the copyright of the right to publish comes later than the protection of the copyright of the right to reproduce. Uniquely, in the 20th and 21st centuries, talk of protection of song or music creation is more prominent than the protection of literary works. Even with regard to the right to publish, the discussion seems to be dominated by the field of song or music creation rather than the field of literary or other creation.

Rationally, because of the widespread use of songs by the public in relation to broadcasting, performing or listening to songs, it is impossible for the composer or the related rights holder themselves to grant licenses, collect royalties, and file cases when someone illegally or without permission to broadcast, show, Therefore, an institution that can represent songwriters and related rights holders is needed, which is known internationally as the collective administration of right or collecting society or institutions that collect royalties for the use of songwritings by the public.

The Collective Management Institution itself in Law Number 28 of 2014 is defined as an institution in the form of a non-profit legal entity that is authorized by creators and copyright holders and / or related rights owners to manage their economic rights in the form of collecting and distributing royalties. Royalties are the amounts paid for the use of property, such as patents, copyrights, or natural resources. This institution acts as an implementer of the protection of the economic rights of creators, especially song or music composers. Talking about the protection of the economic rights of creators, especially song or music composers, ultimately boils down to one thing, namely how to exploit compositions of songs or musicians to generate economic benefits for the composers.

The economic benefit generated from the exploitation of these musical works is royalties. In Indonesia itself, there are many collective management institutions that collect royalties such as WAMI, ASIRI, YKCI and others. The activity of collecting royalties by the Collective Management Institute is solely to represent the interests of the creators, copyright holders, or related rights owners. In this regard, the management of copyright royalties in the field of song or music The National Collective Management Institute must present its representatives as follows:

1. the interests of the Creator; and

2. Related Rights Owner interests. ${ }^{2}$

${ }^{2}$ Abdul Atsar. 2018. Get to know the Law of Intellectual Property Rights. Sinar Grafika, Jakarta, p. 25. 
Therefore, these two collective management institutions have the authority to withdraw, collect, and distribute royalties from commercial users in two forms, namely the Collective Management Institute for the benefit of creators and the Collective Management Institute for the interests of related rights owners. To carry out the collection, the two Collective Management Institutions are required to coordinate and determine the amount of property that is the right of each Collective Management Agency in accordance with the prevalence in practice based on justice. The words prevalence and justice referred to by Law Number 28 of 2014 are as an emphasis on upholding the principles or principles of law of propriety and principles or principles of justice law. Common words indicate the standards that apply in society,

Therefore, the distribution of the proceeds of royalties managed by the Collective Management Agency to the creators or rights holders concerned must fulfill a sense of justice, which then the amount will be regulated by the relevant Ministry. In implementing the royalty collection, LMKN which consists of Collective Management Institutions representing the interests of Creators and Collective Management Institutions representing the interests of related rights owners, through its Commissioners the two LMKs set the Operational Standards for Withdrawal of Royalties, the Coordinator of Withdrawal, Collection and Distribution of Royalties (KP3R) of Creators. and Rights Related to Songs and Music. The Operational Standards for Withdrawal of Royalties The Coordinator of Withdrawal, Collection,

a. KP3R sends a Letter of Introduction and Notification along with LKM profile, License Form, Royalty Rate Decision and other documents to Commercial Users who do not have a license, which must be responded to by the User within 7 (seven) days as accurately as received;

b. If the Commercial User responds to the Letter of Introduction and Notification, KP3R and the Commercial User enter into a License Contract.

c. KP3R reports the License Contract to LMKN.

d. KP3R sends a Payment Bill (invoice) along with a Tax Invoice to commercial users with the logo LMKN, KP3R, LMK Creator and / or LMK Related Rights along with Taxes to be paid the month the invoice is opened;

e. The period for payment of Royalties by Commercial Users is made no later 
than 1 (one) month after the invoice is received;

f. If the Commercial User is late in making payments up to 1 (one) month after the invoice is received, the Commercial User will be subject to a fine of $0.05 \%$ (zero point zero five percent) per day of the invoice amount;

g. KP3R issues certificates \& stickers to Commercial Users who have carried out the obligation to pay royalties;

h. If the Letter of Introduction and Notification to the Commercial User is not responded to, KP3R will issue a Letter of Declaration which the User must respond to within 7 (seven) days;

i. If the Letter of Declaration has not been responded to within 7 (seven) days, the KP3R will issue a final notice;

j. If the Final Notification Letter has not been responded to for 7 (seven) days, then KP3R will take legal action in accordance with the prevailing laws and regulations, with the costs borne by the Commercial User;

k. The License registration fee shall be borne by the Commercial User. ${ }^{3}$

${ }^{3}$ The internet site is www. Imk.id was visited on January 29, 2020, at 20.45 WIB.
In connection with the license to announce songs or music in Indonesia, there is an institution formed to carry out the license, namely the Collective Management Institute (LMK). The Collective Management Institute is an institution that is empowered by the creator to exercise the economic rights of the creator. The creators represented by writers (composers, lyricists, arranger and adapters), music publishers (music publihes), and also copyright recipients (the heirs of writers). One of the known Collective Management Institutions is the Karya Cipta Indonesia Foundation (YKCI) or often called $\mathrm{KCI}$. KCI is a collective management agency that represents song or music composers who register their membership with KCI.

In carrying out its duties to collect royalties for the announcement or use of songs or music by the user, LMK in this case must carry it out based on the Standard Operating Procedure for Withdrawing Royalties that have been formed by the respective LMK Coordinators, namely LMK representing the Creator and LMK representing the interests. related rights that have joined the LMKN.

A sign or proof of a public place that uses licensed songs / music is a license certificate by LKM: 
1. Lisence time period

2. Type of business given

3. Signed signed by the chairman and / or one of the LKMN commissioners.

When linked with the stipulated procedure regarding royalties, the right to publish is given to play or play the entire repertoire managed by $\mathrm{KCI}$, namely millions of songs worldwide in one package and royalties are paid in advance, in accordance with the general concept of licensing. Karaoke places that have paid receive a letter of agreement between the karaoke place and the central KCI, payment receipts and a license certificate issued by the central KCI. The standard of collection of royalties for commercial purposes at karaoke establishments is IDR 10,000,000 (ten million rupiah), which they must pay according to their ability. The minimum payment should be IDR 5,000,000 (Five Million Rupiah). But basically the authorities to collect royalties, in this case $\mathrm{KCI}$, do a minimum of IDR $10,000,000$.

\section{Inhibiting factors for payment of copyright royalties for songs between creators and actors in karaoke entertainment. Case Study Orange family karaoke}

Registration is not a requirement for the validity (recognition) of a copyright, but only to facilitate proof in the event of a dispute.
The purpose of registering a work from a government perspective is actually to provide documents or documents relating to such registration. Related to copyright registration, it is the same with the copyright of a musical work or song. Registration of a musical or song copyright work is seen as something that needs to be done to avoid infringement of the work. In the event of a violation, it will be difficult to prove the creator's status. Registration is regulated in the intended law to regulate the registration of works in order to create public order and order in the field of copyright, especially from an administrative perspective.

Apart from registering copyright with the Director General of Intellectual Property Rights, awareness of cooperation with royalty management agencies must also be considered. The economic rights of the creators are in the form of royalties when the work is produced in various forms and post-production royalties due to announcement and commercial use. But in the exercise of economic rights, it is often exposed to constraints and problems such as optimization of information technology, optimization of collecting royalties, the effectiveness of the Collective Management Institute (LMK).

In practice, the existence of a national royalty collection agency is urgently 
needed. This is considered important because in terms of the use and / or use of a creation it is closely related to royalties, whereas in practice based on Law Number 28 of 2014, royalty management is carried out in collaboration with professional organizations. The professional organization in question is the Collective Management Institute (LMK).

The confusion faced in the practical field is that there are more than one LMK. In practice, to establish a cooperation in the royalty collection system, the creator enters into an agreement in the form of a license in the framework of submitting his creation to LMK to further manage royalties on copyright songs or music. However, what is developing is a dispute between several collective management institutions regarding the collection of royalties and the legitimacy of each institution. For the payment of royalties, karaoke business actors will be given 14 days from collection and if they exceed the predetermined time limit they will not be fined but will be banned. For the royalty payment fees, the karaoke entertainment business actor will pay a fee of IDR 3600,000 .

The background of the LMK in Indonesia which did not run smoothly was caused by disagreements between the LMK, the creators and the LMK producers. There needs to be a synergy of all the elements that support the national copyright system, mutually reinforcing for optimal protection of rights, legal certainty as a necessity, a solid, strong, transparent and accountable LMK and the National LMK as the coordinator of the existing LMK and its existence is still recognized as an independent legal entity with the main objective of facilitating the bureaucracy of music license users by optimally using information technology.

\section{Conclution}

Based on the results of the research and discussion in the previous chapter, the following conclusions can be drawn copyright is the exclusive right of a creator that arises automatically based on a declarative principle after a work is manifested in a tangible form without reducing restrictions in accordance with the provisions of the laws and regulations. By copyright based on Article 40 UUHC 2014, that a protected work, namely, first a protected work includes: in the fields of science, art, and literature, both Works as referred to in paragraph (1) letter are protected as separate Works without prejudice to the Copyright of the original Work, the third Protection as referred to in paragraph (1) and paragraph (2), includes protection of Works. which has not been 
or made an Announcement but has been manifested in a tangible form which allows the reproduction of the work.

Law Number 28 of 2014 concerning Copyright is still not good and clear in applying the regulations on the provision and protection of royalties that have been regulated in this Law. Another obstacle arises because there is still a lack of socialization and understanding in the payment of royalties as well as the cost of paying royalties which is too expensive to become an obstacle for karaoke entertainment business actors because karaoke is not always crowded and not all rooms are used all day.

The suggestions from the author are as follows:

1. In terms of royalty payments and collective management administration, it is not explicitly regulated in the Copyright Law. This often calls for different interpretations and depends on the interpretation of the parties concerned so that very often the issue of royalty payments and collective management organizations is a debate that does not use a reference or basis that can provide legal certainty, therefore it should be regulated in a manner firm and detailed both through laws and regulations. In addition, the government should also participate in the establishment of collective management organizations to provide protection for parties related to copyright, both creators and copyright holders.

2. Suggestions for Collective Management Institutions (LKM) to be more serious in dealing with copyright issues and be more intensive in terms of socializing this copyright issue to the public and to related parties. There should be a firm and official appointment of the parties who should be authorized to collect royalties, so that there is no confusion or doubt from copyright users if they want to make royalty payments.

\section{BIBLIOGRAPHY}

\section{Books :}

OK Saidin, Legal Aspects of Intellectual Property Rights, Revised Edition. Jakarta : Rajawali Pers, 2013.

Sophar Maru Hutagalung, Copyright Position and Role in Development. Jakarta : Sinar Grafika, 2012.

Muhammad Djumana and Djubaedillah, Historical Intellectual Property Rights Theory and Practice in Indonesia.Jakarta : Citra Aditya Bakti, 2014.

Gatot Supramono, Copyright and legal aspects. Jakarta : Rineka Cipta, 2010. 


\section{Scientific Work}

FT Hapsari, The existence of moral rights in copyright in Indonesia. Legal Matters, 41 (3), 2012.

Maria Alfons,. Implementation of Intellectual Property Rights In The Perspective Of A Rule Of Law. Journal of Indonesian Legislation, 14 (3), 2018.

\section{Laws and Regulations:}

1945 Constitution.

Civil Code.

Law No. 28 of 2014 concerning Copyright.

Government Regulation of the Republic of Indonesia Number 16 of 2020 concerning Registration of Works and Related Rights products.

\section{Website:}

The Internet site https://m.hukumonline.com/klinik/det ail/ulasan/c1755/royalti-hak-cipta/ was visited on August 24, 2020, at 19.00 WIB. 